\title{
Countering Terrorism Through Multilateralism: Reviewing the Role of the United Nations
}

\author{
Ayushi Tiwari ${ }^{*} \&$ Parimal Kashyap ${ }^{* *}$ \\ https://doi.org/10.21827/GroJIL.8.1.110-122
}

Keywords

UNITED

NATIONS; $\quad$ COUNTER-TERRORISM;

TERRORISM; MULTILATERALISM; INTERNATIONAL LAW; VIOLENT EXTREMISM

\begin{abstract}
The United Nations (UN) came into being after the world had been ravaged by two World Wars and was on the brink of a Cold War. It was uncharted territory, even for a global organisation, to acknowledge the perils of the new era, which were not limited to regional issues but also included territorial and communal tensions, the arrival of full-fledged nonState organisations and an intrinsic link to politics. The UN has witnessed the development of terrorism as a major international issue. Many of its agencies were conceived as part of its counter-terrorism strategy. It has sought the implementation of this strategy on an operational basis worldwide and brought about cooperation, aid and assistance for the same. This article analyses the history of the UN's role in defining and countering terrorism, along with the reconfiguration of its stance according to the changing times. It lays out various new challenges put forth by terrorism in the $21^{\text {st }}$ century and questions the legitimacy of the UN's current counter-terrorism strategy. While advocating the necessity of the UN as a guide, a watch dog and an initiator, it highlights the major hurdles in a comprehensive plan of action and suggests a way forward to the revise the perception of the threat and realign the existing institutional efforts and policy changes, as well as highlighting the need to reconfigure the responses and techniques used.
\end{abstract}

\section{Introduction}

Terrorism is an omnipresent phenomenon in every part of the world today. It derives its driving force from a diverse set of circumstances, including discrimination, ${ }^{1}$ religious

\footnotetext{
The author is currently an undergraduate student of law at Dr. Ram Manohar Lohiya National Law University, Lucknow (India). She may be contacted at tiwari.ayushi16@gmail.com.

** The author is currently an undergraduate student of law at Dr. Ram Manohar Lohiya National Law University, Lucknow (India). He may be contacted at parimalkashyap97@gmail.com.

1 James A Piazza, 'Repression and Terrorism: A Cross-National Empirical Analysis of Types of Repression and Domestic Terrorism' (2017) 29(1) Terrorism and Political Violence 102-118.
} 
ideals, ${ }^{2}$ economic disparity, ${ }^{3}$ self-determination, ${ }^{4}$ and political ambitions. ${ }^{5}$ In the first instance, responsibility was undoubtedly attributed to the States on whose soil or with whose resources this agenda was being furthered. However, it was soon observed that these forces, often acting as non-State entities, shifted their operations and adapted to any country which had fertile conditions. Thus, uniformity in the recognition of this danger is sought, as opposed to isolated State action, without which its containment is impossible. The United Nations initially acted as a broker of peace, recognising specific acts and formulating policies as punitive action. However, after the attacks on the World Trade Center, its role diverged into seeking normative behaviour from Member States. The UN aimed to send out a clear, immutable message that terrorism was condemned in all forms, and to enforce international standards based on accountability and the application of sanctions by default if any party contributed to the cause of terrorism. ${ }^{6}$ Previously, groups like Al-Qaeda, with Osama Bin-Laden as its leader, were a relatively lesser threat because of their pronounced anti-Western agenda based on Islamic radicalisation. In comparison, in the present times, terrorism has sprung up in various parts of the world with different aims ranging from religious ideals to self-determination, political motives, and overthrowing discriminatory regimes.

Thus, the UN not only grapples with a multifarious threat, but also the lack of a comprehensive yet balanced approach to combat it. With new-found international acceptance, finances, logistics and information at its disposal, it must actively govern the international response to terrorism to prevent the outbreak of sporadic conflicts on these issues. Moreover, its role becomes more important since the threat of terrorism is now 'globalised', ${ }^{7}$ with sufficient indications of the physical and psychological impacts thereof. This article aims to review the approach that the UN and its affiliated bodies have taken to curb terrorism. It examines the foremost efforts made in the Cold War era and subsequently discusses the high voltage approach adopted by the UN post-9/11. It analyses the contemporary challenges that terrorism has posed and the new trends of prevention that have surfaced. Lastly, it seeks to the highlight the lacunae in various approaches and suggest possible ways forward that the UN could take in countering global terrorism as a multi-faceted threat.

\section{The UN Approach Towards Terrorism in the Cold War Period}

The idea of international terrorism was nascent during the institutionalisation of the UN. Hence, naturally, the drafters did not 'fully anticipate the existence, tenacity, and

2 Ruth Stein, For Love of the Father: A Psychoanalytic Study of Religious Terrorism (Stanford University Press 2010); Mariya Y Omelicheva, 'The Ethnic Dimension of Religious Extremism and Terrorism in Central Asia' (2010) 31(2) International Political Science Review 167-186.

3 James A Piazza, 'Rooted in poverty? Terrorism, poor economic development and social cleavages' (2006) 18(1) Terrorism and Political Violence 159-177; James A Piazza, 'Poverty, Minority Economic Discrimination, and Domestic Terrorism' (2011) 48(3) Journal of Peace Research 339-353.

4 See generally, Yonah Alexander and Robert A Friedlander, Self-Determination: National, Regional, And Global Dimensions (Routledge 1980); Robert A Friedlander, 'Terrorism and National Liberation Movements: Can Rights Derive from Wrongs Dialogue' (1981) 31 Case Western Reserve Journal of International Law 281.

5 Seung-Whan Choi and James A Piazza, 'Ethnic Groups, Political Exclusion and Domestic Terrorism' (2014) 27(1) Defence and Peace Economics 37-63.

6 Kent Roach, The 9/11 Effect: Comparative Counter-Terrorism (Cambridge University Press 2011) 21-70.

7 Taofiki Okunola and M Abiodun 'Terror-Globalisation and the Rise of Modern Terrorism' (2018) 67 International Affairs and Global Strategy 1. 
technology of modern-day terrorism' ${ }^{8}$ However, it evolved precipitously in the Cold War era, due to the bipolarity in international politics and proxy wars. Even during this period, the UN was focused on developing an international regime on terrorism by creating criminal justice treaties. After the International Law Commission's attempts to assign definitive fundamentals to the question of 'what is terrorism?' proved futile, ${ }^{9}$ efforts were undertaken by the General Assembly in the wake of the 1972 Munich Olympics bombings. However, they fell short as States disagreed on the distinction between terrorists and revolutionaries. ${ }^{10}$ This discord continued to plague any effort by the General Assembly to establish a global consensus on terrorism. ${ }^{11}$

A significant step towards adopting a 'general' approach towards terrorism was made through General Assembly Resolution 40/61 in 1985. ${ }^{12}$ The UN removed the 'shield of legitimacy' under which terrorists were hiding and States officially accepted acts of terrorism as criminal acts rather than political acts. ${ }^{13}$ On reviewing the contents of the Resolution, the authors observe that it was truly the foundation of what would be known as the Comprehensive Convention on International Terrorism as, unlike other Resolutions, Resolution 40/61 took a very inclusive and wide approach towards terrorism and requested parties to implement the recommendations of the Ad Hoc Committee. ${ }^{14}$ The General Assembly subsequently played a large role in the setting up of a treaty regime on terrorism during the Cold War. On the other hand, the United Nations Security Council (UNSC), though mostly dormant, has long been accused of circumventing the treaty mechanisms of the Cold War era. These allegations find support several of the UNSC's actions, for example the Lockerbie case.$^{15}$ Here, in response to the bombing of a Pan Am Flight, it passed a Resolution directly in conflict with the 1971 Montreal Convention, ${ }^{16}$ by demanding transfer of the accused to a US military base situated in Netherlands. ${ }^{17}$ The UNSC's politically motivated actions worked to weaken the already volatile treaty framework on terrorism and raised questions regarding the viability of the existing mechanisms. Apparently, in view of the difficulty in creating a universally accepted definition of terrorism, the UN shifted its focus to following a piecemeal approach to strengthen the legal regime on terrorism.

The last quarter of the $20^{\text {th }}$ century witnessed a trend of specific treaties relating to terrorist acts. About a dozen treaties relating to specific terrorist acts were concluded from

8 Mark Baker, 'Terrorism and the Inherent Right of Self-Defence (A Call to Amend Article 51 of the United Nations Charter)' (1987) 10 Houston Journal of International Law 25.

9 International Law Commission, 'Documents of the sixth session including the report of the Commission to the General Assembly, Volume II' (1954) A/CN.4/SER.A/1954/Add.1, 117 (observations of the UK).

10 UNGA, 'Draft Convention for the Prevention and Punishment of Certain Acts of Terrorism' UN GAOR $27^{\text {th }}$ Session UN Doc A/C.6/L.850 (1972); John M Murphy, 'United Nations Proposals on the Control and Repression of Terrorism' in M Cherif Bassiouni (ed), International Terrorism and Political Crimes (Charles C Thomas 1975) 499.

11 Jackson Nyamuya Maogoto, 'War on the Enemy: Self-Defense and State-Sponsored Terrorism' (2003) 4 Melbourne Journal of International Law 406, 410.

12 UNGA Res 40/61 (9 December 1985) UN Doc A/RES/40/61.

13 Douglas Kash, 'Abductions of Terrorists in International Airspace and on the High Seas' (1993) 8 Florida Journal of International Law 65, 75-76.

14 Author's comment on UNGA Res 40/61 (n 12).

15 Libyan Arab Jamahiriya v United Kingdom [1992] ICJ Rep 3.

16 Convention for the Suppression of Unlawful Acts against the Safety of Civil Aviation (adopted 23 September 1971, entered into force 26 January 1973) 974 UNTS 14118, art 7.

17 UNSC Res 731 (21 January 1992) UN Doc S/RES/731. 


\section{Countering Terrorism Through Multilateralism: Reviewing the Role of the United}

Nations 113

1963 to the end of the millennium. ${ }^{18}$ These treaties relied on the 'extradite or prosecute' approach, ${ }^{19}$ and ranged from aviation ${ }^{20}$ and nuclear materials ${ }^{21}$ to financing terrorist activities. ${ }^{22}$ These developments were indeed promising, but were not so efficient in the absence of a comprehensive treaty on terrorism, which was soon realised by States and the UN. Hence, in 2000, the UNGA Ad Hoc Committee (established by Resolution 51/210 of 17 December 1996) began working on the Comprehensive Convention on Terrorism (CCT) ${ }^{23}$ However, the Ad Hoc Committee was faced with a similar deadlock as was seen during previous attempts at concluding a Convention. ${ }^{24}$ Nonetheless, after making significant progress in 2000-2001, it was halted by 9/11, until States reached the 'bottomline' position on disputed issues. ${ }^{25}$ In its latest Report, the Committee noted the difficulties in making 'substantive progress' on outstanding issues. ${ }^{26}$ The Convention is far from being concluded and the General Assembly is still debating the definition of terrorism.

\section{The United Nations Approach Towards Terrorism Post-9/11}

The 9/11 attacks were unprecedented in their magnitude. They urged the international community to change its perceptions of threats to world peace. In light of loopholes in the 'specific' treaty regime, the UNSC formulated Resolution $1373,{ }^{27}$ on the basis of its powers

18 Convention on the Prevention and Punishment of Crimes against Internationally Protected Persons, including Diplomatic Agents (adopted 14 December 1973, entered into force 20 February 1977) 1035 UNTS 15410; International Convention against the Taking of Hostages (adopted 17 December 1979, entered into force 3 June 1983) 1316 UNTS 205; Convention for the Suppression of Unlawful Acts against the Safety of Maritime Navigation (adopted 10 March 1988, entered into force 1 March 1992) SUA/CONF/15/Rev.1; Convention on the Marking of Plastic Explosives for the Purpose of Detection (adopted 1 March 1991, entered into force 21 June 1998); International Convention for the Suppression of Terrorist Bombings (adopted 15 December 1997, entered into force 23 May 2001) 2149 UNTS 256.

19 Convention on the Prevention and Punishment of Crimes against Internationally Protected Persons, including Diplomatic Agents (adopted 14 December 1973, entered into force 20 February 1977) 1035 UNTS 15410, art 7; International Convention against the Taking of Hostages (adopted 17 December 1979 , entered into force 3 June 1983) 1316 UNTS 205, art 8; International Convention for the Suppression of Terrorist Bombings (adopted 15 December 1997, entered into force 23 May 2001) 2149 UNTS 256, art 8.1.

20 Convention on Offences and Certain Other Acts Committed on Board Aircraft (adopted 14 September 1963, entered into force 4 December 1969) 704 UNTS 219 art 1; Convention for the Suppression of Unlawful Seizure of Aircraft (adopted 16 December 1970, entered into force 14 October 1971) 860 UNTS 12325; Convention for the Suppression of Unlawful Acts against the Safety of Civil Aviation (adopted 23 September 1971, entered into force 26 January 1973) 974 UNTS 14118.

21 Convention on the Physical Protection of Nuclear Material (adopted 17 December 1979, entered into force 8 February 1987) 1456 UNTS 24631.

22 International Convention for the Suppression of Financing of Terrorism (adopted 9 December 1999, entered into force 10 April 2002) 2178 UNTS 197.

23 UNGA Res 51/210 (17 December 1996) UN Doc A/RES/51/210.

24 UNGA Res 54/110 (2 February 2000) UN Doc A/RES/54/110; UNGA, 'Report of the Ad Hoc Committee established by UN General Assembly Resolution 51/210 of 17 December 1996 on its 6th session' UNGAOR Supp No 37 UN Doc A/57/37 (2002).

25 UNGA, 'Report of the Ad Hoc Committee established by UN General Assembly Resolution 51/210 of 17 December 1996 on its 6th session' UNGAOR Supp No 37 UN Doc A/57/37 and Corr.1 (2002).

26 UNGA, 'Report of the Ad Hoc Committee established by UN General Assembly Resolution 51/210 of 17 December 1996 on its sixteenth session' UNGAOR Supp No 37 UN Doc A/68/37 (8 to 12 April 2013); United Nations, 'Ad Hoc Committee established by General Assembly Resolution 51/210 of 17 December 1996' (United Nations Office of Legal Affairs, 21 November 2018) $<$ legal.un.org/committees/terrorism/> accessed 30 May 2020.

27 UNSC Res 1373 (28 September 2001) S/RES/1373. 
enumerated in Chapter VII of the UN Charter. ${ }^{28}$ This was the first counter-terrorism initiative which was mandatory for all UN Members and sought to ensure global cooperation. Resolution 1373 was an attempt to build a comprehensive legal framework for counter-terrorism measures, laying the foundations for the legislative actions that the UNSC would subsequently take for its counter-terrorism mission. Hence, the introductory text called for a compulsory system to attack the root of the problem, namely financing. ${ }^{29}$ It not only obligated the Member States to freeze funds likely to be utilised in terrorist activities but also to criminalise and prohibit the provision of funds to entities directly or indirectly controlled by terrorists. ${ }^{30}$ One of the most notable developments in this aspect was the setting up of a Sanctions Committee, which monitored the implementation of sanctions over terrorist groups. ${ }^{31}$ This was a step forward from the earlier Convention which only criminalised acts and did not sufficiently address the causes. ${ }^{32}$

The second part aimed to create a reflection of these norms in the domestic laws of Member States. It propounded general principles, such as having effective machinery to prevent the planning, facilitation and commission of such activities, prescribing adequate punishments, the exchange of information and evidence between members and so forth. ${ }^{33}$ Most importantly, it focused on border regulations and immigration. ${ }^{34}$ In consonance with the first part, it put due regard on the symbiotic relationship between the transnational crimes of, inter alia, money laundering, extortion, kidnapping, smuggling and terrorism, which could be thwarted by the implementation of these principles through domestic agencies, and thus urged nations to ratify the pre-existing Conventions and Protocols on these issues. ${ }^{35}$

Resolution 1373 also brought into existence the Counter-Terrorism Committee (the Committee). Much along the lines of the international human rights treaty bodies regime, Resolution 1373 credited the Committee with ushering in a new method of compliance which was based on dialogue and consensus. ${ }^{36}$ Member States were required to submit reports to the Committee periodically, in order to show whether their obligations had been followed. The objective of the Committee was to ensure that States had existing legislative norms as well as adequate executive machinery to prevent terrorist funding ${ }^{37}$ through

28 Charter of the United Nations (adopted 26 June 1945, entered into force 24 October 1945) 1 UNTS 16, art 41.

29 UNSC Res 1373 (28 September 2001) UN Doc S/RES/1373.

30 UNSC Res 1373 (28 September 2001) UN Doc S/RES/1373, paras 1(a)-1(d).

31 UN Security Council, 'Security Council Committee pursuant to resolutions 1267 (1999) 1989 (2011) and 2253 (2015) concerning Islamic State in Iraq and the Levant (Da'esh), Al-Qaida and associated individuals, groups, undertakings and entities' (UNSC) <un.org/securitycouncil/sanctions/1267\#work_and_mandate> accessed 29 May 2020.

32 International Convention for the Suppression of Financing of Terrorism (adopted 9 December 1999, entered into force 10 April 2002) 2178 UNTS 197.

33 Communications Intelligence Gathering Act 2016 (Germany); Agreement Between the United States and the European Union on the Processing and Transfer of Financial Messaging Data from the European Union to the United States for the Purposes of Terrorist Financing Tracking Program (signed 28 June 2010) <treasury.gov/resource-center/terrorist-illicit-finance/Terrorist-FinanceTracking/Documents/Final-TFTP-Agreement-Signed.pdf $>$ accessed 24 May 2019.

34 UNSC Res 1373 (28 September 2001) UN Doc S/RES/1373, para 2(g).

35 UNSC Res 1373 (28 September 2001) UN Doc S/RES/1373, paras 3(c)-3(f).

36 Guidance for the Submission of Reports Pursuant to Paragraph of Security Council Resolution 1373 (2001) of 28 September 2001, available at <http://www.un.org/Docs/sc/committees/1373/guide.htm>.

37 CTC Discussion Paper (Counterterrorism Committee, $24 \quad$ July 2002 ) <www.un.org/Docs/sc/committees/1373 > accessed 25 May 2020. 


\section{Countering Terrorism Through Multilateralism: Reviewing the Role of the United}

Nations 115

international cooperation. ${ }^{38}$ The accomplishments of these agencies were dependent on their approach of gradual prioritisation, instead of imposing uniformity when dealing with State parties. Initially, States were apprehensive to submit to a roadmap laid down by an international organisation. ${ }^{39}$ The Committee examined the human and technical resources of States to put these norms into practice and regulated even those areas which were not covered by Resolution 1373. In the first round itself, all 191 Member States submitted assessment reports and a significant number went forward for the second round of monitoring. There has been a sharp rise in the acceptance of the major international terrorism Conventions and Protocols since the Committee's establishment. ${ }^{40}$

The UNSC had aimed for sweeping reforms in the area of counterterrorism; however, the Resolutions and their implementation seem myopic in light of the challenges posed by modern-day terrorism. Firstly, compliance with these norms is highly subject to budgetary hindrances. Despite financial and technical assistance, there are States that would rather employ their resources to combat economic, health and social crises which are accorded a higher level of priority. ${ }^{41}$ Secondly, in the absence of any penal mechanism, the Committee finds itself in a vacuum when it comes to addressing repeated defaults in the provision of information by any country. Although it has the power to highlight defaults, ${ }^{42}$ there has not been a single case of referral to the UNSC for penalisation. The UNSC did not even attempt to define 'terrorism', and the myriad interpretations by different States further results in a lack of unanimity in deciding on a course of action.

However, the biggest obstruction in the UN's strategy against terrorism does not stem from external factors but from the internal organisational structure. As previously mentioned, Resolution 1373 led to numerous accusations of the UNSC abusing its power, in that it could not exercise the legislative functions accorded to the General Assembly at the behest of merely fifteen members. ${ }^{43}$ The UNSC in turn claimed to derive its powers from Chapter VII of the UN Charter, which allows it to take necessary action when faced with a grave threat to international peace and security. ${ }^{44}$ Moreover, the General Assembly resembled a parliamentary logjam of political clashes and delay, and it was clearly impossible to expect a reasonable measure therefrom after the 9/11 attacks. The Resolution was adopted by a sweeping majority which further cemented its legitimacy. This long-lasting feud resulted in a fractious approach towards counterterrorism. A major problem remained regarding the unestablished hierarchy, as a multiplicity of organs leads to each following their own mandate, resulting in overlapping duties. There is minimal

38 CTC Discussion Paper (Counterterrorism Committee, 22 Nov 2002) 3 <www.un.org/Docs/sc/committees/1373/Stage\%20B.htm> accessed 23 May 2020.

39 Council on Foreign Relations, 'The Global Regime for Terrorism' (Council on Foreign Relations, 31 August 2011) <cfr.org/report/global-regime-terrorism> accessed 23 May 2020.

40 UNSC, 'Fifty-seventh year, 4618th meeting' (4 October 2002) S/PV.4618.

41 Office of the United Nations High Commissioner for Human Rights, 'Human Rights, Terrorism and Counter-terrorism: $\quad$ Fact-sheet No. 32' (OHCHR, 2008) $<$ ohchr.org/documents/publications/factsheet32en.pdf> accessed 28 August 2020, 47.

42 Sebastian von Einsiedel, 'Assessing the UN's Efforts to Counter Terrorism' (United Nations University Centre for Policy Research, Occasional Paper 8, 4 October 2016) <collections.unu.edu/eserv/UNU:6053/AssessingtheUNsEffortstoCounterterrorism.pdf> accessed 28 August 2020.

43 UNSC, 'Fifty-sixth year, 4394 th meeting (resumption 1)' (25 October 2001) S/PV.4394, 7.

44 Bryan C Banks, 'The Security Council as Global Legislator: Using Chapter VII Authority to Redefine the United Nations' Role in Developing International Legal Norms' in Abdul Ghafur Hamid Khin Maung Sein (ed), The Theory and Practice of International Law: Responses to a Variety of International Legal Issues (Serials Publications 2009) 58-60. 
consultation between the entities which consequently leads to redundancy and tasks being handled without a strategy or aggregation of complementary initiatives. ${ }^{45}$ This fragmented methodology has resulted in the directionless working of related entities such as the Counter-Terrorism Action Group. ${ }^{46}$

The immediate effect of the shortcomings of the previous Resolution was the Global Counter Terrorism Strategy. ${ }^{47}$ Formulated in 2006, the Strategy revolves around four pillars which focus on building the capacity of States to prevent and combat terrorism within the framework of the rule of law. ${ }^{48}$ The Strategy borrows significantly from the European Union's Action Plan on Combating Terrorism. ${ }^{49}$ However, this strategy was similar to its predecessor because even though it focused on capacity building and imposing positive obligations on Member States, it failed to induce the political will and commitment necessary to combat terrorism, devise a system of accountability or induce regional or bilateral cooperation. It put the cart before the horse, since it did not prioritise the Member States' distinctive social, political and economic responses before implementing an all-encompassing plan. This was also highlighted in the Secretary General's report pursuant to Resolution 70/291 where the 'deficit in multilateral cooperation' was mentioned in light of the growing technological and financial enhancement of cross-regional terrorism. ${ }^{50}$ It specifically stated that centrality of national ownership, strengthening governance and devising sustainable policies, should be the cornerstone of new Resolutions, along with governmental and non-governmental coordination and less friction between UN organs. ${ }^{51}$ The Sanctions Committee has been relatively more effective but does suffer from transparency issues. ${ }^{52}$

\section{The United Nations' Shift to the Prevention of Violent Extremism}

The rise of organisations such as ISIL, Al-Shabaab and Boko Haram is the latest manifestation of terrorism. Having been defined as violent extremism, ${ }^{53}$ this is a phenomenon which is not only a threat to international peace and security but may also lead to a humanitarian crisis.

The UN has realised the need for a more layered approach towards battling this situation, as recognised by UNSC Resolution 2178, which states that a truly successful approach must be comprehensive in addressing not only military challenges, but also political, socio-economic and financial ones. ${ }^{54}$ This means that efforts should also focus on

45 Alistair Millar, 'Mission Critical or Mission Creep? Issues to Consider for the Future of the UN CounterTerrorism Committee and Its Executive Directorate' (Global Centre on Cooperative Security, 2017) 5.

46 Eric Rosand, 'The G8's Counterterrorism Action Group' (Centre on Global Counter Terrorism Cooperation, May 2009).

47 UNGA Res 60/288 (20 September 2006) UN Doc A/RES/60/288.

48 ibid.

49 Council of the European Union, 'Declaration on Combating Terrorism' (29 March 2004) Doc 7906/04.

50 UNGA 'Activities of the United Nations system in implementing the United Nations Global CounterTerrorism Strategy, Report of the Secretary-General' (20 April 2018) UN Doc A/72/840.

51 ibid.

52 Kimberly Prost, 'Fair Process and the Security Council: A Case for the Office of the Ombudsperson' in AM Salinas de Frias and others (eds), Counter-Terrorism. International Law and Practice (Oxford University Press 2012) 409-424.

53 UNSC Res 2368 (20 July 2017) UN Doc S/RES/2368; Fund for Peace, 'Insurgency Defectors: Dangers and De-Radicalization Processes' (Relief Web, 27 January 2016) <reliefweb.int/report/world/insurgencydefectors-dangers-and-de-radicalization-processes> accessed 23 May 2020.

54 UNSC Res 2178 (24 September 2014) UN Doc S/Res/2178 paras 13-14. 


\section{Countering Terrorism Through Multilateralism: Reviewing the Role of the United}

Nations 117

issues such as de-radicalisation and disengagement, re-integration and addressing terrorist financing instead of the typical preventive security measures. ${ }^{55}$

In his report, the Secretary General laid down the target groups of these entities, which are primarily people disillusioned with government. The majority of recruits come from a disenfranchised youth, who are readily indoctrinated due to their impressionable minds and are thus easier to control in militant units. ${ }^{56}$ The fundamental reasons for this are a lack of opportunities, in particular regarding education and employment; a sense of discrimination and exclusion; and the oppressive nature of some counterterrorism measures which result in the destruction of civilian homes and communities, leading to a large number of these recruits being below the age of $25 .^{57}$

This challenge has led the UN to introduce International Development Plans to reestablish areas ravaged by conflict and combat the plague of ideology that exploits the disgruntled mindset of vulnerable groups. ${ }^{58}$ This marked the first shift in the UN's approach, in which it broadened its focus from merely perpetrators to also victims. Consequently, international policy swayed from having a narrow focus on security towards a more holistic approach that prioritises development, human rights, democratic governance, engaging youth in opportunities and decision-making processes and reversing violations of international humanitarian law or human rights law.

The rise of violent extremism also presented new threats to the ever-changing dynamics of the global terrorism landscape. ${ }^{59}$ Organisations such as ISIL and ANF popularised the practice of recruiting foreign fighters to unprecedented levels. ${ }^{60}$ The UNSC's concerns regarding this dimension of the spreading of violent extremism were obvious. ${ }^{61}$ The Council, in its Resolution 2178 , aimed to deal with the threat by placing a variety of obligations on States. ${ }^{62}$ Interestingly, the scope of the Resolution is extremely broad and vague. Instead of clearly defining the categories of activities or persons that would fall under its scope, the Council uses the term 'foreign terrorist fighters', stating that this concerns all forms and manifestations of terrorism. ${ }^{63}$ The Council does not limit its scope to international terrorism, and it certainly does not define what terrorism is. It once again leaves it to States to decide and identify who falls under this category. It is a missed opportunity that the UNSC, with the adoption of Resolution 2178, did not refer to

55 UN Secretary-General, 'UN Secretary-General's Remarks at General Assembly Presentation of the Plan of Action to Prevent Violent Extremism' (United Nations, 15 January 2016) $<$ un.org/sg/statements/index.asp?nid=9388> accessed 23 May 2020.

56 UNGA, 'Plan of Action to Prevent Violent Extremism' (24 December 2015) UN Doc A/70/674.

57 ibid.

58 Eric Rosand, Alistair Millar and Jason Ipe, 'Civil Society and the UN Global Counter-Terrorism Strategy: Opportunities and Challenges' (Center on Global Counterterrorism Cooperation, September 2008) <globalcenter.org/wp-content/uploads/2008/09/civil_society.pdf> accessed 28 August 2020.

59 Orla Hennessy, 'The Phenomenon of Foreign Fighters in Europe' (International Centre for CounterTerrorism, July 2012) <icct.nl/download/file/ICCT-Hennessy-Phenomenon-of-Foreign-FightersEurope-July-2012.pdf> accessed 7 August 2020, 3.

60 European Parliament, 'Combating Terrorism' (European Parliament, September <europarl.europa.eu/RegData/etudes/BRIE/2017/608682/EPRS_BRI(2017)608682_EN.pdf>

2017) accessed 7 August 2020.

61 UNSC Res 2178 (24 September 2014) UN Doc S/RES/2178.

62 ibid.

63 UNSC Res 2178 (24 September 2014) UN Doc S/RES/2178, para 7. 
Resolution 1566, in which it came up with a definition of terrorism, in order to limit the scope of the Resolution and avoid the risk of its disproportionate use. ${ }^{64}$

\section{Solving the Definitional Puzzle: The Question of 'What'}

As discussed above, international law gradually advanced through treaties on specific crimes which are indicative of terrorism, for example plane hijacking, ${ }^{65}$ hostage-taking, ${ }^{66}$ and crimes involving nuclear materials ${ }^{67}$ While the 'specific' approach has been relatively successful as compared to the almost non-existent 'general' approach, it cannot be the final solution to the problem. Supporters of the specific approach argue that it not only avoids political disagreement but, above all, it is practical and allows agreements to be concluded..$^{68}$

However, in the age of organised violent extremist groups, the essence of 'terrorism' cannot be captured by referring to specific acts that relate to the idea thereof. It also blurs the distinction between terrorist acts and criminal acts. For instance, under South African law, hijacking a plane for mercenary reasons will also amount to a terrorist act, for it is an offence under international Conventions against hijacking and the taking of hostages. ${ }^{69}$ Therefore, the 'specific' approach sees a departure from the foundational tenets of terrorism, significantly 'producing terror' ${ }^{70}$ More importantly, terrorism as a concept is ever-expanding and recent times have seen it in newer forms. ${ }^{71}$ Following a specific approach and reaching a new agreement after the emergence of these new forms of terrorism will not only be too onerous a task for the international community, but it will also be inefficient in tempering the growth of terrorism across the globe. Global terrorism is perpetrated by terrorists; therefore, the instruments must address terrorists and not specific terrorist acts.

Analysing various attempts made in the Cold War and post-Cold War eras, we conclude that the international community is gradually bridging the discord and the intrinsic problem of definition is not as pronounced as it used to be. Nonetheless, the UN's sustained efforts to reach a consensus have prompted regional organisations to reach an agreement on their respective levels. The European Union's Framework Decision on Combating Terrorism is a standout example of this. ${ }^{72}$ The UN, therefore, must adhere to its mission of adopting a widely accepted definition of terrorism. ${ }^{73}$ Devising an all-inclusive

64 Bibi van Ginkel, 'The New Security Council Resolution 2178 on Foreign Terrorist Fighters: A Missed Opportunity for a Holistic Approach' (International Centre for Counter-Terrorism, 4 November 2014) $<$ icct.nl/publication/the-new-security-council-resolution-2178-on-foreign-terrorist-fighters-a-missedopportunity-for-a-holistic-approach/> accessed 23 May 2020.

65 Convention for the Suppression of Unlawful Seizure of Aircraft (adopted 16 December 1970, entered into force 14 October 1971) 860 UNTS 12325.

66 International Convention against the Taking of Hostages (adopted 17 December 1979, entered into force 3 June 1983) 1316 UNTS 205.

67 Convention on the Physical Protection of Nuclear Material (adopted 17 December 1979, entered into force 8 February 1987) 1456 UNTS 24631.

68 Geoffrey Levitt, 'Is “Terrorism” Worth Defining?' (1986) 13 Northwestern University Law Review 102.

69 South African Anti-Terrorism Bill (2002) cl 1(a).

70 Jennifer Trahan, 'Terrorism Conventions: Existing Gaps and Different Approaches' (2002) 8 New England Journal of International \& Comparative Law 215, 222.

71 UNGA, 'Activities of the United Nations system in implementing the United Nations Global CounterTerrorism Strategy Report of the Secretary-General' (20 April 2018) UN Doc A/72/840.

72 Council Framework Decision 2002/475/JHA of 13 June 2002 on Combating Terrorism [2002] L 164/3.

73 Susan Tiefenbrun, 'A Semiotic Approach to a Legal Definition of Terrorism' (2003) 9 ILSA Journal of International and Comparative Law 357, 365. 


\section{Countering Terrorism Through Multilateralism: Reviewing the Role of the United}

Nations 119

definition is an impossible task. Hence, the focus should be on solving the political disputes relating to the distinction between self-determination movements from acts of terrorism. Some scholars propose that instead of strictly focusing on the definition, States could insert an annex to the Comprehensive Convention on International Terrorism (CCIT), listing prevalent terrorist organisations. ${ }^{74}$ They propose that such a list could be monitored and periodically updated by an independent body. ${ }^{75}$ This idea does not sound plausible, as most of the definitional conflicts on terrorism are only in reference to the differing character and motivations of terrorist organisations. ${ }^{76}$ Currently, the Sanctions Committee, under the UNSC, functions in a similar manner with respect to the list of organisations on which sanctions are to be imposed. However, as previously discussed, the functioning of the Sanctions Committee was rendered ineffective due to transparency issues. To ensure transparency and fairness, States could borrow from the United Nations Framework Convention on Climate Change's successful model of 'Conference of the Parties' (CoP), ${ }^{77}$ to monitor and update the list. States could decide on the status of controversial organisations through a democratic system. An inclusive setup would provide muchneeded legitimacy to the CCIT.

\section{The Drawbacks of the 'War' against Terrorism}

Past practices have shown that military force plays a central role in weakening and often ending well-organised and relatively large terrorist groups. ${ }^{78}$ The military defeat of ISIL at the hands of Iraqi armed forces, assisted by the US-led coalition's air forces, only exemplifies the efficiency of military force in crippling terrorist organisations. ${ }^{79}$ However, heralding this as a victory over ISIL would be a myopic interpretation of terrorism, and the growth of regional groups such as Islamic State of West Africa and the Khorasan group cements this view. ${ }^{80}$ The inability of military strength to eradicate terrorist groups is attributable to the fact that terrorist groups are constituted by their ideology, which cannot be defeated by arms alone. ${ }^{81}$ Another factor that contributes to the bluntness of military strength in countering terrorism is the mobile nature of terrorist organisations. ${ }^{82}$ Therefore, when military force weakens organisations such as Al-Qaeda or the Taliban in Afghanistan, they transfer their activities and focus to neighbouring regions, making

74 Sara De Vido, 'The future of the draft UN convention on international terrorism' (2017) 3(3) Journal of Criminological Research, Policy and Practice 233-247.

75 ibid.

76 Tiefenbrun (n 73).

77 United Nations, 'Conference of the Parties (COP)' (United Nations Climate Change) $<$ unfccc.int/process/bodies/supreme-bodies/conference-of-the-parties-cop> accessed 28 August 2020.

78 Audrey K Cronin, 'How al-Qaida Ends: The Demise and Decline of Terrorist Groups' (2006) 31 International Security 7.

79 Lara Seligman, 'U.S.-led Coalition Set to Launch Final Fight Against ISIS in Syria' (Foreign Policy, 1 August 2018) <foreignpolicy.com/2018/08/01/u-s-led-coalition-set-to-launch-final-fight-against-isis-insyria/> accessed 23 May 2020.

80 Jacob Zenn, 'ISIS in Africa: The Caliphate's Next Frontier' (Centre for Global Policy, 26 March 2020) <cgpolicy.org/articles/isis-in-africa-the-caliphates-next-frontier/> accessed 29 May 2020; see also Kabir Taneja, 'End of the Islamic State, but not the end of ISIS' (Observer Research Foundation, 25 March 2019) <orfonline.org/expert-speak/end-of-the-islamic-state-but-not-the-end-of-isis-49249/>_accessed 29 May 2020.

81 Paul R Pillar, 'The Diffusion of Terrorism' (2010) 21(1) Mediterranean Quarterly 1-14; Dipak K Gupta, Understanding Terrorism and Political Violence: The Life Cycle of Birth, Growth, Transformation, and Demise (Routledge 2008).

82 David Galula, Counterinsurgency Warfare: Theory and Practice (Praeger 1964) 72. 
themselves equally impactful in wider areas. ${ }^{83}$ This phenomenon perhaps explains why only seven percent of terrorist groups have 'ended' as a result of military force. ${ }^{84}$

In fact, military force unintentionally contributes to the radicalisation of terrorist ideologies. ${ }^{85}$ The legitimacy of the US-led NATO invasion in Iraq remains a matter of debate. However, the brutality of the conflict, leading to the birth of ISIS in Iraq, ${ }^{86}$ adds substantial value to claims of the counter-productivity of military strategy in combating terrorism in the long-term. ${ }^{87}$ With that being said, long-term schemes to counter terrorism must not rely on military strength.

Even when military strength is to be applied, the UN and its allied organisations ought to ensure that principles of the conduct of engagement, or jus in bello, are upheld. Powerful States have attempted to justify their questionable actions by adopting diverging interpretations of laws, such as the United States on the issue of Guantanamo Bay. ${ }^{88}$ Such interpretations have resulted in gross violations of the principles of human rights and humanitarian law. The use of autonomous weapons, such as drones in Yemen and Pakistan, ${ }^{89}$ also raised numerous questions. ${ }^{90}$ Despite the disturbances and terrorist activities, these are peaceful States. Hence, legally, the employment of such weapons and measures results in nothing but extra-judicial civilian killings and violations of human rights law. ${ }^{91}$

The genesis of the problem lies in the inability of the General Assembly to maintain its role as the guardian of the UN Charter. The General Assembly, without a doubt, is competent to discourage and condemn targeted killings as a breach of the principles of the UN Charter. However, its failure to exercise strong measures is greatly disheartening. ${ }^{92}$ The General Assembly regularly passes Resolutions to counter terrorism..$^{93}$ It emphasises the importance of international cooperation and lawful conduct while asking States 'to make best use of the existing institutions of the UN' in their quest to curb international

83 Martin C Libicki, 'The Limits of America's al Qa'ida Strategy' in Seth G Jones and Martin C Libicki (eds), How Terrorist Groups End: Lessons for Countering al Qa'ida (RAND 2007) 111-114.

84 Seth G Jones, 'How Terrorist Groups End' in Seth G Jones and Martin C Libicki (eds), How Terrorist Groups End: Lessons for Countering al Qa'ida (RAND 2007) 19.

85 Philip Vertigans and Philip Sutton, "The role of anti-terror measures in the development of "Islamic" terrorism' (2006) 4(4) International Journal of Humanities 87.

86 Seth G Jones, 'How Terrorist Groups End' in Seth G Jones and Martin C Libicki (eds), How Terrorist Groups End: Lessons for Countering al Qa'ida (RAND 2007) 89.

87 William Maley, 'Transitioning from military interventions to long-term counter-terrorism policy: The case of Afghanistan (2001-2016)' (International Centre for Counter-Terrorism, April 2016) $40<\mathrm{icct}$.nl/wpcontent/uploads/2016/04/transitioning_from_military_intervention_afghanistan_2016.pdf> (accessed 7 August 2020.

88 Third Geneva Convention Relative to the Treatment of Prisoners of War 1949 (adopted 12 August 1949, entered into force 21 October 1950) 75 UNTS 135, art 5; Protocol Additional to the Geneva Conventions of 12 August 1949 and Relating to the Protection of Victims of International Armed Conflicts (Protocol I) (adopted 8 June 1977, entered into force 7 December 1978) (API) 1125 UNTS 3, art 51.

89 CNN, 'US Kills Cole Suspect' (CNN Online, 5 November 2002) <edition.cnn.com/2002/WORLD/meast/11/04/yemen.blast/index.html> accessed 7 August 2020.

90 Chris Downes, 'Targeted Killings in an Age of Terror: The Legality of the Yemen Strike' (2004) 9 JCSL 277.

91 David Kretzmer, 'Targeted Killing of Suspected Terrorists: Extra-Judicial Executions or Legitimate Means of Defence?' (2005) 16 EJIL 171.

92 Nigel D White, Keeping the Peace: The United Nations and the Maintenance of International Peace and Security (Manchester University Press 1997) 173-8.

93 UN, 'Measures to eliminate international terrorism (Agenda item 109)' (United Nations) <un.org/en/ga/sixth/74/int_terrorism.shtml> accessed 28 August 2020. 


\section{Countering Terrorism Through Multilateralism: Reviewing the Role of the United}

terrorism. ${ }^{94}$ These statements are at best ambiguous and do little to check terrorism or violations of the UN Charter by States. In the absence of a community response to violations, the legitimacy of the Charter provisions is being sabotaged. One of the foundational principles of the United Nations was to avoid conflict, let alone those conflicts followed by more catastrophic counterblows. Military force is an exception, international cooperation is the rule and it is the duty of the United Nations to ensure that it remains that way.

\section{Winds of Change}

One of the most remarkable innovations in the field of counterterrorism has been regarding peacekeeping missions. With a view to encouraging more States to participate in counterterrorism initiatives, the UN set up an All Sources Information Fusion Unit (ASIFU) for its peacekeeping mission in Mali. The UNSC carefully aligned the mandate of MINUSMA with the UN Global Counter-Terrorism Strategy and gave it a greater role than previous peacekeeping missions. ${ }^{95}$ The mandate also stressed disarmament, demobilisation and reintegration mechanisms. The overhaul of purely military peacekeeping missions is a relatively new tool in the UN's peace and security toolbox, yet the initial success of MINUSMA shows that such multidimensional peacekeeping missions can play an important role in preventing violent extremism in vulnerable regions. ${ }^{96}$

The UN's involvement in Central Asia, in the Joint Plan of Action including five Central Asian countries, also paved the way for less intervention and more coordination with national governments, especially in Tajikistan and Kyrgyzstan, where it made good on its promise to aid States in the enhancement of a cooperative regime. ${ }^{97}$ Though the position of the UN's Preventive Diplomacy Offices in these countries was conveniently downgraded later, ${ }^{98}$ it was a rare occasion where the reasons for this stemmed from the UN's acts of promoting dialogue on an international level between disgruntled governments and exiled citizens instead of gross violations of sovereignty, human rights or a domestic plan of action.

\section{Conclusion}

As the preceding chronology confirms, the pattern of the past two decades has been one of expanding and deepening UN engagement in counterterrorism. There have been pauses, perhaps a retreat or two, but the overall direction has been unambiguous. Continuing disagreements over a comprehensive definition have not prevented either the General Assembly from endorsing an ever-expanding set of proscribed actions or the UNSC from adding - through unanimous votes - one layer of counter-terrorism mechanisms after

94 UNGA Res 64/118 (15 January 2010) UN Doc A/RES/64/118; UNGA Res 65/34 (10 January 2011) UN Doc A/RES/65/34.

95 UNSC Res 2295 (29 June 2016) UN Doc S/RES/2295.

96 Natasja Rupesinghe and others, 'Assessing the Effectiveness of the United Nations Mission in Mali (MINUSMA) Report 4/2019' (Norwegian Institute of International Affairs, 2019) <nupi.brage.unit.no/nupixmlui/bitstream/handle/11250/2599513/EPON-MINUSMA-Report-Exec-

Summary.pdf?sequence $=2>$ accessed 7 August 2020 .

97 United Nations Regional Centre for Preventive Diplomacy for Central Asia, 'The Joint Plan of Action for Central Asia' (United Nations, 2020) <unrcca.unmissions.org/joint-plan-action> accessed 01 June 2020.

98 Miroslav Jenca, 'The Concept of Preventive Diplomacy and Its Application by the United Nations in Central Asia' (2013) 24(2) Security and Human Rights 183-194. 
another. Efforts such as these usually involve a high, often looked-down-upon, intervention in the monitoring of the legislative processes of the Member States. Even in its extensive pursuit to innovate and implement these strategies, the United Nations still commands a modest, even marginal position in the global counter-terrorism campaign. ${ }^{99}$ In light of the challenges highlighted above, it has struggled to maintain any effective role in dictating the direction of counter-terrorism measures. This is also complemented by the inherent limits on its ability to contribute to this area. ${ }^{100}$

As a general rule, most Member States have preferred to keep such sensitive matters as their counter-terrorism agendas out of global fora - particularly the UN's political bodies - where they fear further politicisation of the local issues in dispute. Once the General Assembly, or even the UNSC, is seized of such an issue, the course of deliberations tends to become increasingly difficult to control or to predict. As a result, throughout most of its existence, the United Nations has been discouraged by those Member States which are affected by the bulk of terrorist incidents. ${ }^{101}$

The UN has achieved the insurmountable feat of global acceptance of its mandates without having to wield an iron fist, except in drastic situations. However, it is this which makes the task of ensuring compliance even tougher. Whether it is about exchanging information between nations or making a joint alliance in a region, it is presumptive to think that a mere push shall result in phenomenal change. This is where the importance of dialogue and consensus becomes paramount. Communication should not be a two-way channel between the State party concerned and the UN, but a multilateral discussion between allies, opponents and the UN. Not only would this guarantee transparency and dialogue, but it would also legitimise UN intervention in the event of discord. Terrorism is an evolving phenomenon and it is next to impossible to nip each causal circumstance in the bud. Hence, the UN must be attuned to this dynamic threat to world peace and security. Similarly, States certainly have the primary responsibility to prevent and counter terrorism, with the acknowledgement of the role of civil societies in preventing radicalisation of ideologies amongst youth at local level.

Almost two decades after 9/11, there is general agreement on the idea that the phenomenon as such will probably not end, and that actions against terrorist groups or networks require long-term counter-terrorism policies. Despite several military interventions against terrorism, our understanding of the link between military interventions and counter-terrorism policies is still remarkably limited. In particular, the link between the closure of military interventions and the establishment and implementation of long-term counter-terrorism policies is not well understood and has remained under-researched. An evolving threat needs an evolving plan of action, spearheaded by one but supported by everyone.

grojil.org

99 Edward C Luck, 'The Uninvited Challenge: Terrorism Targets the United Nations' in Edward Newman et al (eds), Multilateralism Under Challenge: Power, International Order, And Structural Change (United Nations University Press 2009) 348.

100 ibid.

${ }^{101}$ Naureen Chowdhury Fink, Meeting the Challenge: A Guide to United Nations Counterterrorism Activities (International Peace Institute 2012) 21. 